\title{
Anti-corrosion Performance of Chromium-coated Steel in a Carbon Dioxide-saturated Simulated Oilfield Brine
}

\author{
Yisheng $\mathrm{Hu}^{1 *}$, Yu Peng ${ }^{1}$, Feng $\mathrm{Hu}^{2}$, Fangzhou He ${ }^{l}$, Ping Guo ${ }^{1}$ \\ ${ }^{1}$ State Key Laboratory of Oil and Gas Reservoir Geology and Exploitation, Southwest Petroleum \\ University, Chengdu, 610500, China \\ ${ }^{2}$ Sichuan Geophysical Company, CNPC, Chengdu, 610213, China \\ *E-mail: huyisheng008@yahoo.com
}

doi: $10.20964 / 2017.06 .94$

Received: 10 March 2017 / Accepted: 28 April 2017 / Published: 12 May 2017

\begin{abstract}
A protective chromium coating was prepared on $\mathrm{P} 110$ steel by pack cementation. The corrosion behavior of the coated P110 steel in a $\mathrm{CO}_{2}$-saturated simulated oilfield brine was investigated by static complete immersion tests and electrochemical measurements. The capacitive loop and polarization resistance decreased with increasing immersion time. The temperature of the $\mathrm{CO}_{2}$-saturated simulated oilfield brine also affected the corrosion behavior. The formation and degradation of the passivation film on the steel were analyzed based on the immersion time and temperature dependence of the electrochemical properties.
\end{abstract}

Keywords: Oilfield brine; Corrosion; Electrochemical impedance spectroscopy; Carbon dioxide

\section{$\underline{\text { FULL TEXT }}$}

(C) 2017 The Authors. Published by ESG (www.electrochemsci.org). This article is an open access article distributed under the terms and conditions of the Creative Commons Attribution license (http://creativecommons.org/licenses/by/4.0/). 